Vol 3 No 2 (2020) 233-251 P-ISSN 2620-295 E-ISSN 2747-0490 DOI: 1047467/elmal.v3i2.571

\title{
Analisis Peningkatan Kinerja Karyawan Melalui Pelatihan dan Pengembangan pada Bank Muamalat Cabang Medan Balai Kota
}

\author{
Asmawarna Sinaga1, Anjur Perkasa Alam², Ahmad Daud³, Raras Aprilia Br.Barus4, \\ Syahrizal Amri ${ }^{5}$ \\ STAI Jam'iyah Mahmudiyah Tanjung Pura Langkat \\ Asmawarna.sinaga@yahoo.co.id, anjurpohan@gmail.com
}

\begin{abstract}
.
Analysis of employee performance improvement through training and development at Bank Muamalat Medan City Hall Branch. Analysis of Asmawarna Sinaga and Anjur Perkasa Alam. Work is one form of worship performed in the world. Working with the right work ethic according to Islamic teachings is an absolute requirement to achieve happiness in this world and the hereafter. Because, using good ethics can increase work morale which has an effect on increasing work productivity. Training and development is a process to train new employees or employees who will get a new placement with the basic skills needed to carry out their work and the focus of the training is on the current job. Meanwhile, for the long-term nature and aimed at developing the ability of employees for the tasks to be faced in the future, it is called development. The research design uses a qualitative approach. While the data analysis technique uses content analysis and interactive methods consisting of data reduction, data collection, data presentation and drawing conclusions. The results of this study indicate that the Branch Head and Employees of Bank Muamalat Medan City Hall are very good, friendly, polite and thorough. The way employees work in improving service quality is very good. Customer response is also very good.
\end{abstract}

Keynote: employee performance, training and development

\section{ABSTRAK}

Analisis peningkatan kinerja karyawan melalui pelatihan dan pengembangan pada Bank Muamalat Cabang Medan Balai Kota. Analisis Asmawarna Sinaga dan Anjur Perkasa Alam. Bekerja adalah salah satu bentuk ibadah yang dilakukan di dunia. Bekerja dengan etika kerja yang benar sesuai ajaran islam merupakan syarat mutlak untuk mencapai kebahagiaan dunia dan akhirat. Sebab, dengan menggunakan etika yang baik dapat meningkatkan semangat kerja yang berpengaruh dalam meningkatkan produktivitas kerja. Pelatihan dan pengembangan adalah proses untuk melatih para karyawan baru atau karyawan yang akan memperoleh penempatan baru dengan keterampilan dasar yang diperlukan untuk melaksanakan pekerjaannya dan fokus dari pelatihan tersebut adalah untuk pekerjaan sekarang. Sedangkan yang untuk sifatnya jangka panjang dan bertujuan untuk mengembangkan kemampuan karyawan untuk tugas yang akan dihadapi mendatang disebut pengembangan. Desain penelitian menggunakan pendekatan kualitatif. Sedangkan teknik analisis data menggunakan content analysis dan metode interaktif yang terdiri dari reduksi data, pengumpulan data, penyajian data dan penarikan kesimpulan. Adapun hasil penelitian ini bahwa Kepala Cabang dan Karyawan Bank Muamalat Cabang Medan Balai Kota sangat baik, ramah, sopan serta teliti. Cara kerja karyawan dalam meningkatkan kualitas pelayanan sangat baik. Respons nasabah juga sangat baik.

Kata Kunci: Kinerja Karyawan, Pelatihan dan Pengembangan. 


\section{| Jurnal Kajian Ekonomi \& Bisnis Islam}

\section{Vol 3 No 2 (2020) 233-251 P-ISSN 2620-295 E-ISSN 2747-0490 DOI: 1047467/elmal.v3i2.571}

\section{PENDAHULUAN}

Didirikannya bank syariah dilatar belakangi oleh keinginan umat islam untuk segera menghindari riba di dalam semua kegiatan muamalahnya, memperoleh kesejahteraan lahir bantin melalui kegiatan muamalah yang sesuai dengan perintah islam, sebagai alternatif lain dalam menikmati jasa-jasa perbankan yang dirasakannya lebih sesuai, yaitu bank-bank yang berusaha sebisamungkin untuk beroperasi berlandaskan kepada hukum-hukum syariat isla. Diawali dengan pengkajian ilmu ekonomi syariah indonesia yang dimulai sejak tahun 70 -an namun ternyata perkembangannya mulai marak pada dekade 90-an.

Perkembangan ekonomi syariah di Indonesia boleh dikatakan mengalami perkembangan yang cukup pesat. Hal ini di tandai dengan banyak berdirinya lembaga keuangan yang secara operasional menggunakan prinsip bagi hasil atau dikenal dengan prinsip syariah (Ridwan, 2004).

Perkembangan zaman terus melangkah maju dan banyak menyumbangkan perubahan-perubahan, membangun tatanan dan peradaban baru, seperti ideologiideologi kemanusiaan, life style, dan sebagainya. Perilaku budaya dan sosial manusia telah banyak mengabaikan moralitas, nilai persahabatan yang manusiawi, bahkan lebih condong pada materi, kekuasaan, kehormatan, kesenangan duniawi, dan lebih mementingkan dunianya sendiri (Kamaluddin dan Muhammad Arfan, 2010). Hal ini terjadi karena orientasi kehidupan manusia saat ini hanya ingin menguasai, meskipun pada hakikatnya manusia saat ini hanya dikuasai oleh emosi dan nafsunya.

Demikian pula yang terjadi pada umat islam saat ini, masih dikuasai oleh emosi dan nafsunya. Berdasarkan konteks sejarah, umat islam pernah mengalami masa kejayaan tahun 610-1250 M dan juga masa kemunduran. Faktor yang menyebabkan kemunduran umat islam salah satunya adalah adanya pengekangan berfikir, serta masalah pendidikan dan pengajaran yang merupakan tujuan diutusnya para Nabi (Kamaluddin dan Muhammad Arfan, 2010). Rasulullah SAW, Bersabda "sesungguhnya aku diutus untuk menyempurnakan akhlak".

Oleh sebab itu, etika menjadi bagian paling penting dalam islam. Salah satu tokoh etika dalam islam adalah Ibnu Miskawaih. Demi memperoleh kebahagiaan dunia dan akhirat agama islam mengajarkan agar umatnya melakukan kerja keras baik dalam bentuk ibadah maupun amal sholeh. Ibadah adalah perintah yang harus dilakukan oleh umat islam yang berkaitan langsung dengan Allah SWT dan telah ditentukan secara terperinci tentang tatacara pelaksanaannya. Sedangkan amal sholeh adalah perbuatan baik yang dilakukan oleh umat islam, dimana perbuatan tersebut berdampak positif bagi dirinya sendiri, bagi masyarakat, bagi bangsa dan negara, serta bagi umat islam itu sendiri (Suseno, 1997).

Dalam perspektif Islam dengan pendekatan Al-Qur'an maupun sunnah, syarat pokok mengenai upah adalah majikan harus memberi upah kepada para pekerjanya 


\section{Vol 3 No 2 (2020) 233-251 P-ISSN 2620-295 E-ISSN 2747-0490 DOI: 1047467/elmal.v3i2.571}

secara penuh dan harus sesuai dengan jasa yang telah mereka (para pekerja) berikan kepada pihak perusahaan. Sedangkan para pekerja harus melakukan pekerjaan mereka dengan sebaik-baiknya. Setiap kegagalan dalam memenuhi syarat ini akan dianggap sebagai kegagalan moral baik dipihak majikan atau pekerja. Hal itu harus mereka pertanggung jawabkan kepada tuhan. Dalam hal ini Islam membuktikan keunggulannya terhadap sekularisme menegenai persoalan ekonomi (Mannan, 1994).

Jenis bank di Indonesia dibedakan menjadi dua yaitu bank yang melakukan usaha secara syariah yang mengandalkan sistem bagi hasil (profit sharing) (Kasmir, 2006). Adapun sejarah berdirinya perbankan dengan sistem bagi hasil, berdasarkan atas alasan utama yaitu adanya pandangan bahwa bunga (interest) pada bank konvensional hukumnya haram karena termasuk dalam kategori riba yang dilarang dalam semua agama. Dalam jangka panjang sistem perbankan konvensional akan menyebabkan penumpukan kekayaan pada segelintir orang yang memiliki modal besar (Syahdeni, 2005).

Para ahli menyatakan bahwa produkvitas pegawai akan meningkat apabila kepada mereka diberikan insentif. Pemberian insentif diharapkan dapat meningkatkan produktivitas kerja pegawai sehingga kerja pegawai bergairah bekerja dalam upaya pencapaian tujuan perusahaan dengan menawarkan perangsang finansial dan melebihin upah dasar. Yang harus diperhatikan adalah pemberian insentif harus dilaksanakan tepat pada waktunya, agar dapat mendorong setiap karyawan untuk bekerja secara lebih baik dari keadaan sebelumnya dan meningkatkan produktivitasnya.

Insentif merupakan penghargaan atau ganjaran yang diberikan untuk memotivasi para pegawai agar produktivitasnya tinggi dan sifatnya tidak tetap atau sewaktu-waktu. Pada dasarnya pemberian insentif bukanlah hak tetapi penghormatan terhadap pegawai yang telah menunjukan kemampuannya dan prestasi kerja yang baik dalam melaksanakan tugasnya hal ini dimaksudkan untuk memotivasi kerja.

Upah para pekerjaanya, tapi akan lebih etis lagi apabila perusahaan juga ikut memperhitungkan berapa kepala yang bergantung pada sang pekerja tersebut (Arifin dan Abdul Aziz, 2013). Pemberian upah kepada tenaga kerja dalam suatu kegiatan produksi pada dasarnya merupakan imbalan/balas jasa kepada tenaga kerja atas prestasinya yang telah disumbangkan dalam kegiatan operasionalnya. Upah tenaga kerja yang diberikan tergantung pada: Biaya keperluan hidup minimum pekerja dan keluarganya, peraturan undang-undang yang mengikat tentang upah minimum pekerja (UMR), produktivitas marginal tenaga kerja, Tekanan yang dapat diberikan oleh serikat buruh dan serikat pengusaha, perbedaan jenis pekerjaan. Upah yang diberikan oleh para pengusaha secara teoritis dianggap sebagai harga dari tenaga yang dikorbankan pekerja untuk keuntungan perusahaan.

Ekonomi syariah telah mengimplementasikan institusi dan kajian keislamannya, kini memperlihatkan prospektif yang menggembirakan. Hal tersebut terlihat dari Kesuksesan Bank Muamalat Indonesia sebagai perbankan syariah yang pertama yang 


\section{Vol 3 No 2 (2020) 233-251 P-ISSN 2620-295 E-ISSN 2747-0490 DOI: $1047467 /$ elmal.v3i2.571}

beroperasi di Indonesia sejak berdiri 1 Mei pada tahun 1992, hingga kini telah berkembang semakin pesat. Walaupun pada awalnya pendirian Bank Muamalat Indonesia keberadaan bank syariah ini belum mendapat perhatian yang optimal dalam tatanan industri perbankan nasional (Antonio, 2000).

Sumber daya manusia merupakan salah satu aset terpenting bagi perusahaan. Peran sumber daya manusia bagi perusahaan tidak hanya dilihat dari hasil produktivitas kerja tetapi juga dapat dilihat dari kualitas kerja yang dihasilkan, bahkan lebih jauh keunggulan suatu perusahaan juga ditentukan oleh keunggulan daya saing manusianya bukan ditentukan lagi oleh sumber daya alamnya. semakin kuat pengetahuan(knowledge) dari sumber daya manusia suatu perusahaan akan semakin kuat daya saing perusahaan tersebut. Setiap manusia memilikikemampuan, keahlian, dan kreativitas yang tidak sama. Kemampuan, keahlian dan kreativitas tidak bekerja optimal jika tidak diasah dengan adanya pengembangan.

Pengembangan tenaga kerja menjadi salah satu kegiatan yang penting dalam perusahaan dimana karyawan dan perusahaan bekerja sama secara balance untuk eksistensi perusahaaan. Hal ini dapat dilakukan dengan meningkatkan keterampilan dan pengetahuan tenaga kerja yang diwujudkan dalam berbagai bentuk nyata, misalnya: pemberian pelatihan, mengadakan seminar-seminar, pemberian kursus pelatihandan lain-lain. Perusahaan harus memilih cara pengembangan yang sesuai dengan tujuan perusahaan agar hasilnya mencapai sasaran. Potensi setiap karyawan harus diketahui oleh perusahaan sebelum melakukan program pengembangan, karena mengetahui potensi ini, dapat diarahkan jenjang karir yang sesuai dengan kemampuannya sehingga dapat menghasilkan produktivitas yang optimal.

Tanpa memiliki sumber daya manusia yang kompetitif, sebuah perusahaanakan mengalami kemunduran dan akhirnya dapat tersisih karena ketidak kemampuannya dalam menghadapi pesaing, kondisi seperti itu mengharuskan perusahaan untuk melakukan pembinaan karier bagi para pekerja. Salah satu fungsi manajemen sumber daya manusia adalah pengembangan, pengembangan karyawan sangat bermanfaat untuk karyawan dan masa depan perusahaan guna menghindari adanya penurunan kinerja perusahaan dari kemajuan era globalisasi. Zaman serba modern ini, perusahaan sudah banyak menggunakan fasilitas canggih maka tenaga kerja yang perusahaan miliki disesuaikan dengan bekal pelatihan agar bisa bekerja dengan baik. Sumber daya manusia dalam suatu perusahaan memerlukan peningkatan atau pengembangan agar dicapai suatu hasil kerja yang optimal, maka perlunya suatu institusi apapun memiliki unit atau devisi atau departemen yang menangani pengembangan sumber daya manusia atau Human Resources Development (HRD).

Sumber daya manusia merupakan salah satu aset terpenting bagi perusahaan. Peran sumber daya manusia bagi perusahaan tidak hanya dilihat dari hasil produktivitas kerja tetapi juga dapat dilihat dari kualitas kerja yang dihasilkan, bahkan lebih jauh keunggulan suatu perusahaan juga ditentukan oleh keunggulan daya saing manusianya 


\section{Vol 3 No 2 (2020) 233-251 P-ISSN 2620-295 E-ISSN 2747-0490 DOI: 1047467/elmal.v3i2.571}

bukan ditentukan lagi oleh sumberdaya alamnya. semakin kuat pengetahuan (knowledge) dari sumber daya manusia suatu perusahaan akan semakin kuat daya saing perusahaan tersebut. Setiap manusia memiliki kemampuan, keahlian, dan kreativitas yang tidak sama. Kemampuan, keahlian dan kreativitas tidak bekerja optimal jika tidak diasah dengan adanya pengembangan.

Pengembangan tenaga kerja menjadi salah satu kegiatan yang penting dalam perusahaan dimana karyawan dan perusahaan bekerja sama secara balance untuk eksistensi perusahaaan. Hal ini dapat dilakukan dengan meningkatkan keterampilan dan pengetahuan tenaga kerja yang diwujudkan dalam berbagai bentuk nyata, misalnya: pemberian pelatihan, mengadakan seminar-seminar, pemberian kursus pelatihan dan lain-lain.

Perusahaan harus memilih cara pengembangan yang sesuai dengan tujuan perusahaan agar hasilnya mencapai sasaran. Potensi setiap karyawan harus diketahui oleh perusahaan sebelum melakukan program pengembangan, karena mengetahui potensi ini, dapat diarahkan jenjang karir yang sesuai dengan kemampuannya sehingga dapat menghasilkan produktivitas yang optimal.

Semakian meningkatnya perbankan syariah di Indonesia, maka peran yang dijalankan perbakan syariah sagatlah penting dalam mengatur peredaran uang dan sektor moneter di Indonesia. Mengingat oerbanjan syariah di Indonesia termasuk salah satu satu sistem perbankan yang baru. Namun, perbankan syariah sekarang ini telah memegang peranan yang sangat penting dalam perekonomian masyarakat. Sebab perbankan syariah adalah sebuah badan usaha yang bergerak dalam sektoe jasa yang mengacu pada prinsip-prinsip syariah dan aktifitasnya mengumpulkan dana dari masyarakat dan kemudian kembali menyalurkan kepada masyarakat dalam bentuk pendanaan maupun pembiayaan. Hal ini membuktikan dengan adanya kepercayaan dari masyarakat terhadap perbankan syariah yang semakain tinggi.

Salah satu pengelolaan paling penting dalam dunia perbankan di samping pemasaran adalah pengelolaan terhadap sumber daya manusia (SDM). Hal ini disebabkan sumber daya manusia merupakan tulang punggung dalam menjalankan roda kegiatan operasional suatu bank. Disamping itu sumber daya manusia yang dimiliki oleh bank haruslah memiliki kemampuan dalam menjalankan setiap transaksi perbankan, mengingat faktor pelayanan yang diberikan oleh para karyawan ini sangat menentukan sukses atau tidaknya bank kedepan. Kemampuan yang telah dimiliki haruslah terus diasah secara terus menerus, baik melalui pengalaman kerja maupun pelatihan pengembangan karyawan (Kasmir, 2000).

Agar keberadaan sumber daya manusia memiliki kontribusi atau peran yang maksimal dalam pencapaian misi dan tujuan organisasi, perlu dilakukan upaya peningkatan kualitas secara komperhensif dan terus menerus. Salah satu upaya meningkatkan kualitas sumber daya manusia itu adalah melalui pelatihan dan pengembangan. 


\section{| Jurnal Kajian Ekonomi \& Bisnis Islam}

\section{Vol 3 No 2 (2020) 233-251 P-ISSN 2620-295 E-ISSN 2747-0490 DOI: 1047467/elmal.v3i2.571}

Pelatihan dan pengembangan memiliki kontribusi besar dalam organisasi karena dapat berfungsi sebagai agen of change terhadap individu dalam organisasi. Pelatihan dan pengembangan dapat menjadi media atau wahana untuk melakukan transfer atau internalisasi nilai-nilai strategis organisasi, membangun budaya organisasi, kompetensi inti rganisasi kepada anggota atau individu. Pelatiah dan pengembangan dalam konteks ini merupakan wahana atau media untuk meningkatkan semangat dan mendongkrak kinerja sejalan dengan standar kinerja yang telah ditetapkan. Sebab pelatihan dilakukan sebagai solusi terhadap problem kinerja individu (Sudarmanto, 2009).

Serangkaian program pelatihan yang diberikan oleh perusahaan dan perbankan biasanya menggunakan dua metode, metode yang pertama yaitu metode on the job training dan off the job training. Metode on the job training merupakan latihan merupakan latihan yang diberikan kepada calon karyawan sambil bekerja. Artinya calon karyawan sudah terlibat bekerja dengan bimbingan rekan-rekan atau karyawan lama yang sudah terlibat bekerja dengan rekan-rekan atau karyawan yang sudah berpengalaman. On the job training dilakukan dengan memantau dan melaksanakan pekerjaan (Kasmir, 2000). Metode off the job training merupakan metode presentasi dan simulasi untuk mengajarkan berbagai sikap konsep atau keterampilan kepada peserta dan menerima representasi tiruan suatu aspek organisasi dan diminta untuk menanggapinya seperti dalam keadaan sebenarnya (Kasmir, 2000).

Kinerja merupakan salah satu kunci yang paing penting bagi organisasi ataupun perusahaan sebab setiap perusahaan tidak dapat mengalami peningkatan hanya dari upaya satu atau dua orang saja melainkan dari keseluruhan upaya anggota perusahaan. Organisasi yang dapat menghasilkan kinerja yang baik tentu tidak terlepas dari hasil kinerja yang dicapai oleh anggota-anggotanya (Kmbey, dkk, 2016).

Adapun rumusan masalah yang peneliti ungkapkan dalam penelitian ini adalah sebagai berikut: Bagaimana Aplikasi pelatihan dalam peningkatan kinerja karyawan Bank Muamalat Cabang Medan ? dan Bagaimana peranan pelatihan dan pengembangan dalam peningkatan kinerja karyawan Bank Muamalat Cabang Medan?

Adapun tujuan dari penelitian adalah sebagai berikut: untuk mengetahui bagaimana Aplikasi pelatihan dalam peningkatan kinerja karyawan Bank Muamalat Cabang Medan dan peranan pelatihan dan pengembangan dalam peningkatan kinerja karyawan Bank Muamalat Cabang Medan.

\section{TINJAUAN LITERATUR}

Perbankan Syariah adalah bank yang menjalankan perintahnya sesuai dengan prinsip syariah. Dimana yang dimaksud dengan prinsip syariah adalah aturan perjanjian berdasarkan hukum islam antar bank dan pihak lain untuk menyimpan dana dan atau pembiayaan untuk kegiatan lainnya yang dinyatakan sesuai dengan syariah, antara lain pembiayaan berdasarkan prinsip bagi hasil, pembiayaan berdasarkan prinsip penyertaan modal, prinsip jual beli barang dengan memperoleh keuntungan, atau 


\section{Vol 3 No 2 (2020) 233-251 P-ISSN 2620-295 E-ISSN 2747-0490 DOI: 1047467/elmal.v3i2.571}

pembiayaan berdasarkan prinsip sewa murni tanpa pilihan, atau dengan adanya pilihan pemindahan kepemilikan atas barang yang disewakan dari pihak bank ke pihak lain.

Menurut Undang-undang RI Nomor 10 Tahun 1998 tanggal 10 November 1998 tentang perbankan adalah badan usaha yang menghimpun dana dari masyarakat dalam bentuk-bentuk lainnya dalam rangka meningkatkan taraf hidup rakyat banyak (Kasmir, 2010). Sedangkan Menurut Undang-undang Nomor 21 tahun 2008 tentang perbankan syariah, "Perbankan Syariah" adalah segala sesuatu yang menyangkut tentang bank syariah dan unit usaha syariah, mencakup kelembagaan, kegiatan usaha, cara dan proses dalam melaksanakan kegiatan usahanya Dengan demikian perbankan syariah dapat dipahami secara detail. Bank syariah adalah lembaga keuangan yang disesuaikan dengan prinsip-prinsip syariah.

Menurut Perwaatmadja "Bank Syariah adalah bank yang tata cara operasinya mengikuti ketentuan-ketentuan syariah Islam". Salah satu yang harus dijauhi dalam muamalah Islam adalah praktik-praktik yang mengandung unsur riba. Sedangkan menurut Bank Syariah adalah Bank yang beroperasi dengan tidak mengandalkan pada bunga. Yakni mengacu kepada ketentuan-ketentuan Al-quran dan Hadis (Kasmir, 2011).

Dimana yang dimaksud dengan perbankan syariah adalah segala sesuatu yang menyangkut tentang Bank Syariah dan Unit Usaha Syariah, mencakup kelembagaan, kegiatan usaha, serta cara dan proses dalam melaksanakan kegiatan usahanya. Perbankan Syariah merupakan bank yang menerapkan nilai-nilai syariah salah satu diantaranya pelarangan unsur riba, seperti dijelaskan di beberapa ayat Al-Qur'an dalam Surat Al-Imran :130 sebagai berikut :

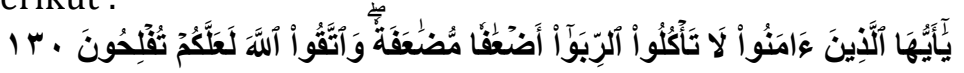

Artinya : "Hai orang-orang yang beriman, janganlah kamu memakan riba dengan berlipat ganda dan bertakwalah kamu kepada Allah supaya kamu mendapat keberuntungan".( Alquran dan terjemah, 2010).

Dari ayat diatas, dapat dijelaskan tentang pengertian riba, yaitu : yang dimaksud riba di sini ialah riba nasi'ah. menurut sebagian besar ulama bahwa riba nasi'ah itu selamanya Haram, walaupun tidak berlipat ganda. Riba itu ada dua macam: nasiah dan fadhl. riba nasiah ialah pembayaran lebih yang disyaratkan oleh orang yang meminjamkan. riba fadhl ialah penukaran suatu barang dengan barang yang sejenis, tetapi lebih banyak jumlahnya Karena orang yang menukarkan mensyaratkan demikian, seperti penukaran emas dengan emas, padi dengan padi, dan sebagainya. riba yang dimaksud dalam ayat Ini riba nasiah yang berlipat ganda yang umum terjadi dalam masyarakat Arab zaman Jahiliyah.

Allah Swt berfirman mengenai riba dalam An Nisa : 39, yaitu :



Artinya :"Dan disebabkan mereka memakan riba, padahal Sesungguhnya mereka Telah dilarang daripadanya, dan Karena mereka memakan harta benda orang dengan jalan 


\section{| Jurnal Kajian Ekonomi \& Bisnis Islam}

\section{Vol 3 No 2 (2020) 233-251 P-ISSN 2620-295 E-ISSN 2747-0490 DOI: 1047467/elmal.v3i2.571}

yang batil. kami Telah menyediakan untuk orang-orang yang kafir di antara mereka itu siksa yang pedih" (Al-quran dan terjemah, 2010).

Permasalahn riba inilah yang menjadi tolak ukur nasabah lebih memilih menyimpan uangnya di Bank Syariah. Sistem bagi hasil yang ditawarkan oleh Bank Syariah ini lah yang sangat menarik minat nasabah.

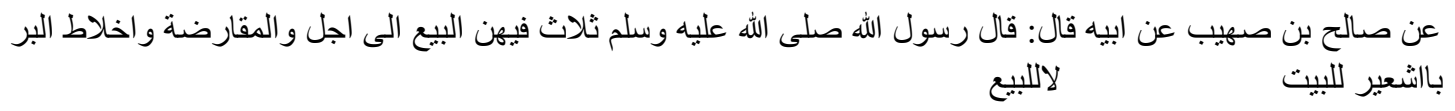

Artinya: "Dari Shahih bin Shuhaib r.a. bahwa Rasulullah saw. Bersabda, "Tiga hal yang di dalamnya terdapat keberkatan: jual beli secara tangguh, muqaradhah (mudharabah), dan mencampur gandum dengan tepung untuk keperluan rumah, bukan untuk dijual". (HR. Ibnu Majah)

Selain itu, berdirinya perbankan syariah tentu saja memiliki tujuan secara umum dan khusus. Secara umum tuujuan didirikannya perbankan syariah adalah dapat memberikan sumbangan terhadap pertumbuhan ekonomi masyarakat melalui pembiayaan yang dikeluarkan oleh perbankan syariah. Kemudian secara khusus tujuan bank syariah adalah : Menjadi perekat nasionalisme baru, artinya bank syariah dapat menjadi fasilitator aktif bagi tebentuknya jaringan ekonomi syariah, Memberdayakan ekonomi masyarakat dan beroperasi secara transparan, artinya pengelolaan bank syariah harus didasarkan pada visi ekonomi kerakyatan dan upaya ini terwujud bila ada mekanisme operas yang transparan, Mendorong penurunan spekulasi di pasar keuangan, artinya bank syariah lebih mengarahkan dananya pada transakasi peroduktif, Meningkatkan efisiensi mobilisasi dana dan Uswah hasanah sebahai implementasi moral dalam penyelenggaraan usaha bank (Muhammad, 2006).

Bank syariah memiliki beberapa ciri-ciri dan karakteristik antara lain: Berdimensi keadilan, Adanya pemberlakuan jaminan, Menciptakan rasa kebersamaan, Bersifat mandiri, Persaingan secara sehat dan Adanya dewan pengawas syariah.

\section{Kinerja}

Bekerja adalah salah satu bentuk ibadah yang dilakukan di dunia. Bekerja dengan etika kerja yang benar sesuai ajaran islam merupakan syarat mutlak untuk mencapai kebahagiaan dunia dan akhirat. Sebab, dengan menggunakan etika yang baik dapat meningkatkan semangat kerja yang berpengaruh dalam meningkatkan produktivitas kerja. Hal ini dkarenakan nilai etika, moral, atau akhlak adalah nilai-nilai yang mendorong manusia menjadi pribadi yang utuh seperti kejujuran, kebenaran, keadilan, kemerdekaan, kebahagiaan, dan cinta kasih. Setiap orang boleh mempunyai seperangkat pengetahuan, tetapi pengetahuan yang mengarahkan dan mengendalikan perilaku orang islam hanya ada dua yaitu Al-Qur'an dan Hadist sebagai sumber segala nilai dan pedoman dalam setiap sendi kehidupan, termasuk dalam bisnis (Hasan, 2009). 


\section{Vol 3 No 2 (2020) 233-251 P-ISSN 2620-295 E-ISSN 2747-0490 DOI: 1047467/elmal.v3i2.571}

Dari penjelasan diatas dapat ditarik kesimpulan bahwa sesungguhnya penghayatan agama yang diwujudkan dalam bentuk iman yang sempurna, mempunyai hubungan timbal balik dengan etika atau akhlak seseorang. Seseorang yang memiliki iman yang sempurna, dipastikan memiliki etika kerja yang baik pula. Karena etika kerja islami tidak mengajarkan untuk mendurhakai Allah dalam bekerja. Yaitu dengan meningkatkan kejujuran, keadilan, dan semangat dalam bekerja sehingga target dapat tercapai dengan meningkatnya produktivitas tanpa adanya tindakan yang menyimpang seperti korupsi.

Kinerja adalah prestasi kerja yang merupakan hasil dari implementasi rencana kerja yang dibuat oleh suatu instansi yang dilaksanakan oleh pimpinan dan karyawan (sumber daya manusia) yang bekerja di Institusi itu baik pemerintah maupun perusahaan untuk mencapai tujuan organisasi (Abdullah, 2014).

Menurut Mamik Eko Supatmi dkk, bahwa secara konseptual kinerja adalah hasil kerja yang dicapai oleh seseorang dalam kurung waktu tertentu berdasarkan standar kerja yang telah ditetapkan oleh sebuah peruasahaan, dan mencapai hasil kerja berdasarkan standar kerja yang telah ditetapkan (Eko, dkk, 2000).

Kinerja adalah hasil-hasil fungsi pekerja atau kegiatan seseorang atau kelompok dalam suatu organisasi yang dipengaruhi oleh berbagai faktor untuk mencapai tujuan organisasi dalam waktu tertentu (Ardila, 2006). Fungsi pekerjaan yang dimaksud adalah pelaksanaan hasil pekerjaan atau kegiatan seseorang atau kelompok yang menjadi wewenang dan tanggung jawab dalam suatu organisasi. Sedangkan faktor-faktor yang berpengaruh terhadap hasil pekerjaan seseorang atau kelompok terdiri dari faktor internal dan eksternal.

Perkembangan peran perbankan syariah tidak terlepas dari sistem perbankan di Indonesia secara umum, peran bank syariah dalam memacu pertumbuhan daerah semakin strategis dalam rangka mewujudkan struktur perekonomian yang semakin berimbang. Dukungan terhadap pengembangan perbankan syariah juga diperlihatkan dengan adanya "dual banking system", dimana bank konvensional di perkenankan untuk membuka Unit Usaha Syariah.

Pertumbuhan dan perkembangan bank syariah dapat dilihat dari semakin banyaknya jumlah jaringan kantor. Peningkatan jumlah jaringan kantor bank syariah tersebut memicu peningkatan jumlah tenaga kerja atau sumber daya manusia yang dibutuhkan untuk menjalankan kegiatan operasional perbankan syariah.

Tenaga kerja merupakan pilar utama yang memiliki kontribusi besar terhadap jalannya aktivitas pengelolaan jasa perbankan, Waktu, tenaga dan kemampuannya benar-benar dapat dimanfaatkan secara optimal bagi bank, maupun kepentingan individu (Fathani, 2006).

Hak Upah yang layak menjadi hal yang paling sensitif karena upah merupakan jaminan yang menyangkut kesejahteraan pekerja. Kompensasi dalam bentuk upah bentuk upah merupakan salah satu fungsi yang penting dalam manajemen sumber daya 


\section{| Jurnal Kajian Ekonomi \& Bisnis Islam}

\section{Vol 3 No 2 (2020) 233-251 P-ISSN 2620-295 E-ISSN 2747-0490 DOI: 1047467/elmal.v3i2.571}

manusia (MSDM). Karena Upah merupakan salah satu aspek yang paling sensitif di dalam hubungan kerja antara perusahaan dengan pekerjanya (Sustrisno, 2010).

Kinerja perusahaan adalah hasil dari kegiatan manajemen. Salah satunya manajemen sumber daya manusia yang berperan penting dalam peningkatan kinerja perusahaan. Parameter yang sering digunakan untuk menilai kinerja suatu perusahaan dengan menggunakan pendekatan dimana informasi keuangan diambil dari laporan keuangan atau laporan lainnya.Kinerja juga suatu prestasi yang dicapai oleh seseorang dalam melaksanakan tugas atau pekerjaannya, sesuai dengan standar kriteria yang ditetapkan dalam pekerjaan itu. Prestasi yang dicapai ini akan menghasilkan suatu kepuasan kerja yang nantinya akan berpengaruh pada karir. Suatu kinerja individu dapat ditingkatkan apabila ada kesesuaian antara pekerjaan dan kemampuan yang dilatih dari pengembangan. Dalam hal ini dibutuhkan suatu evaluasi, yang kemudian dikenal dengan penilaian kinerja.

\section{Peningkatan Kinerja Karyawan}

Secara umum upah merupakan segala sesuatu yang diterima karyawan, buruh, atau pekerja sebagai balas jasa atas kerja yang telah dilakukan. Upah juga bisa dikatakan sebagai imbalan yang diberikan kepada tenaga kerja langsung yang hasil kerjanya dapat diukur dengan satuan tertentu (jumlah fisik barang yang dihasilkan atau masa atas jasa pekerjaan yang diserahkan).

Pemberian upah kepada buruh atau pekerja hendaklah berdasarkan atas jasa dan keadilan yang artinya adil bagi buruh atau pekerja atas apa yang dikerjakan nya serta mampu untuk memenuhi kebutuhan hidup layak. Besarnya upah mencerminkan nilai karya mereka diantara para buruh atau pekerja atas apa yang telah mereka kerjakan. Oleh karena itu, bila para buruh atau pekerja merasa pemberian upah yang tidak mencukupi maka produktifitas kerja mereka akan menurun secara drastis di mana hal ini tentunya akan berpengaruh terhadap jalannya aktifitas perusahaan.

Adapun masalah yang sering terjadi di dunia ketenagakerjaan yaitu tentang hal yang menyangkut hak-hak pekerja terutama untuk diperlakukan secara baik dalam lingkungan pekerjaan, dan hak upah yang layak (Suhrawardi, 2000). Masalah ini terjadi karena biaya kebutuhan hidup kaum buruh dari hari ke hari terus meningkat yang ditunjukan oleh peningkatan Indeks Harga Konsumen (IHK). Namun, di pihak lain para pengusaha atau pemilik selalu mencoba menekan biaya dalam kondisi ketidakstabilan ekonomi dalam negeri (Syafei, 2006).

Keseimbangan dalam lingkup kerja yang menyangkut mengenai pengupahan tersebut, akan terwujud dengan kewenangan otonomi pemerintah daerah setempat dengan menetapkan standar upah minimum berdasarkan upah minimum profinsi dan perhitungan kebutuhan hidup layak dengan memperhatikan tingkat perekonomian di masing-masing sektor di wilayah tersebut sebagai acuan dalam penetapan standar upah bagi setiap perusahaan. 


\section{| Jurnal Kajian Ekonomi \& Bisnis Islam}

\section{Vol 3 No 2 (2020) 233-251 P-ISSN 2620-295 E-ISSN 2747-0490 DOI: 1047467/elmal.v3i2.571}

Suatu perkembangan dan pembangunan ekonomi memerlukan peran serta lembaga keuangan sebagai penyedia dana. Maka dari itu suatu lembaga keuangan ikut berperan aktif. Adapun salah satu lembaga keuangan yang ikut berperan adalah bank. Menurut Undang-Undang No. 10 Tahun 2008, bank adalah badan usaha yang menghimpun dana dari masyarakat dalam bentuk kredit dan menyalurkan kredit dan atau bentuk lainnya dalam rangka meningkatkan taraf hidup orang rakyat banyak (UU RI,1992).

Dalam kamus besar bahasa Indonesia upah ialah "uang yang dibayarkan sebagai pembalas jasa atau pembayaran tenaga yang sudah lakukan untuk mengerjakan sesuatu" (Phoenix, 2009) Pimpinan yang baik akan membayar upah sesuai dengan tingkat kerjanya.

Upah didefinisikan sebagai balas jasa yang adil dan layak diberitahukan kepada para pekerja atas jasa-jasanya dalam mencapai tujuan organisasi. Upah merupakan imbalan finansial langsung dibayarkan kepada karyawan berdasarkan jam kerja, jumlah barang yang dihasilkan atau banyaknya pelayanan yang diberikan (Rivai, 2004).

Adapula yang mengatakan "Upah ialah suatu penerimaan sebagai imbalan dari pemberi kerja kepada penerima kerja termasuk tunjangan, baik untuk pekerja sendiri maupun keluarganya" (Winami dan Sugiyarso, 2006)

Pada masanya, Rasulullah adalah pribadi yang menetapkan upah bagi para pegawainya sesuai dengan kondisi, tanggung jawab dan jenis pekerjaan. Proses penetapan gaji yang pertama kalidalam Islam bisa dilihat dari kebijakan Rasulullah untuk memberikan gaji satu dirham setiap hari kepada Itab bin Usaid yan diangkat sebagai Gubernur Mekkah (Sinn, 2006).

Permasalahan lain yang terdapat dalam meningkatkan produktivitas kerja adalah motivasi kerja. Target suatu perusahaan akan dapat tercapai apabila kinerja dari karyawan yang ada didalamnya memiliki motivasi kerja yang tinggi. Di dalam Al-Qur'an terdapat ayat yang menyuruh dan memotivasi bekerja. Dengan bkerja dan berpenghasilan manusia dapat memenuhi kebutuhannya. Dalam surat Al-Jum'ah ayat 10 Allah telah menegaskan :

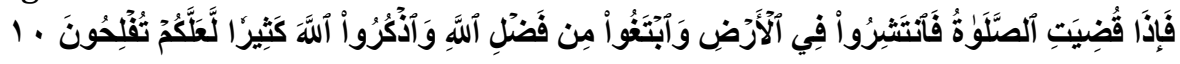

Artinya : "Apabila telah ditunaikan shalat, maka bertebaranlah kamu dimuka bumi, dan carilah karunia Allah dan ingatlah Allah banyak-banyak supaya kamu beruntung" (Alquran dan terjemah, 2013).

Persaingan yang ketat atau tuntutan nasabah terhadap pelyanan bank yang lebih sempurna merupakan faktor pendorong adanya inovasi dan ada nya perubahan bisnis perbankan. Nasabah telah mengakui dan menyadari apa yang sesungguhnya di inginkan nasabah dan memilih apa yang terbaik. Dipihak lain nasabah juga tidak menginginkan prosedur yang panjang dan rumit untuk setiap transaksi perbankan. Kenyamanan dan kemudahan menjadi tujuan perusahaan perbankan. 


\section{Vol 3 No 2 (2020) 233-251 P-ISSN 2620-295 E-ISSN 2747-0490 DOI: 1047467/elmal.v3i2.571}

Untuk menjawab tantangan diatas bank syariah berlomba-lomba meningkatkan pelayanan dengan menonjolkan dan mengoptimalkan keunggulan komparatifnya serta menyiapkan diri untuk meningkatkan kemampuan bersaing melalui perbaikan pelayanan terhadap nasabahnya. Masing-masing bank berusaha menampilkan dirinya sebaik mungkin agar dapat menarik minat nasabah untuk menabung.

Kualitas pelayanan merupakan jaminan terbaik dari kesetiaan pelanggan. Kualitas pelayanan yang lebih tinggi akan menghasilkan kepuasan nasabah yang tinggi pula. Oleh karena itu program penyempurnaan kualitas pada umumnya akan meningkatkan profitabilitas nasabahnya.

Pada umumnya, kunci untuk memenangkan persaingan adalah memberikan kepuasan kepada konsumennya., sehingga terciptanya sebuah keputusan pada konsumen untuk menggunakan jasa. Pada tahap inilah bank harus menyenangkan hati konsumen agar konsumen tertarik pada setiap produk-produk yang ditawarkan, salah satu strateginya adalah dengan meningkatkan kualitas pelayanan. Di harapkan dengan kualitas pelayanan yang baik, maka kepuasan konsumen akan tercapai sehingga dengan adanya kepuasan, keputusan akan tercipta.

Selain dengan meningkatkan kualitas pelayanan, ternyata komunikasi juga sangat penting, karena tanpa adanya komunikasi yang baik, maka kualitas pelayanan tidak akan terlaksana dengan baik. Salah satunya dengan menggunakan komunikasi interpersonal. Komunikasi interpersonal adalah proses penyampaian, penerimaan pesan antara pengirim pesan dengan penerima pesan baik secara langsung maupun tidak langsung (Suranto, 2011). Setelah terjadinya pertukaran informasi antara penerima pesan dan pengirim pesan diharapkan terjadi sebuah perubahan perilaku. Dengan layanan komunikasi yang baik akan berpengaruh positif terhadap keputusan menjadi nasabah.

Kepuasan konsumen merupakan evaluasi bagi sebuat perusahaan yang ingin memajukan usahanya. Untuk mendapatkan kepuasan, maka perlu mengetahui harapan yang diinginkan oleh para nasabahj. Terdapat tiga faktor yang dapat dikendalikan oleh pemasar yang mempengaruhi kepuasan nasabahnya, yaitu : kualitas pelayanna, kualitas produk dan harga. Sedangkan dua faktor lainnnya, yaitu : faktor situasional dan faktor personal diluar kendali perusahaan (Suryani, 2008).

Terdapat lima faktor utama yang harus diperhatikan dalam menentukan tingkat kepuasan nasabah, yaitu: Kualitas produk, Kualitas pelayanan, Emosional, Harga dan Biaya.

Faktor internal yang mempengaruhi kinerja karyawan dari kecerdasan, keterampilan, kestabilan, emosi, motivasi, persepsi peran, kondisi keluarga, kondisi fisik, seseorang dan karakteristik kelompok kerja dan sebagainya. Sedangkan pengaruh faktor eksternal antara lain peraturan ketenagakerjaan, kegiatan pelanggan, persaingan, nilai sosial, serikat buruh, kondisi ekonomi, perubahan lokasi kerja dan lokasi pasar. 


\section{| Jurnal Kajian Ekonomi \& Bisnis Islam}

\section{Vol 3 No 2 (2020) 233-251 P-ISSN 2620-295 E-ISSN 2747-0490 DOI: 1047467/elmal.v3i2.571}

Bekerja merupakan kewajiban setiap muslim, sebab dengan bekerja setiap muslim mengaktualisasikan kemuslimannya. Karena manusia adalah akhlik cipta Allah yang paling sempurna dan mulia di atas dunia. Hal ini sesuai dengan firman Allah Swt QS. Al-Jumu'ah: 10, yaitu :

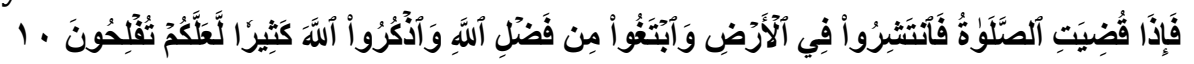

Artinya: Apabila Telah ditunaikan shalat, Maka bertebaranlah kamu di muka bumi; dan carilah karunia Allah dan ingatlah Allah banyak-banyak supaya kamu beruntung (Alquran dan terjemah, 2013).

Pengukuran kinerja karyawan sealu memperhatikan kualitas pekerjaan, kualitas dan ketepatan waktu. Kualitas adalah keseluruhan ciri serta sifat dari suatu produk atau jasa yang berpengaruh pada kemampuannya untuk memuaskankebutuhan yang dinyatakan atau yang tersirat (Kotler, 2000). Salah satunya adalah kualitas layanan yang diberikan kepada para nasabah.

Kualitas layanan dapat didefinisikan sebagai seberapa jauh perbedaan antara kenyataan dan harapan para pelanggan atas layanan yang mereka terima. Kualitas layanan dapat diketahui dengan cara membandingkan persepsi para pelanggan atas layanan yang benar-benar telah mereka terima.

Kualitas layanan sebagai ukuran seberapa baik tingkat yang diberikan mampu sesuai dengan harapan pelanggan. Kualitas layanan adalah tingkat keunggulan yang diharapkan dan pengendalian atas tingkat keunggulan tersebut untuk memenuhi keinginan pelanggan.

Dalam mengevaluasi kepuasan terhadap produk jasa, atau perusahaan tertentu, nasabah umumnya mengacu pada berbagai faktor atau dimensi. Faktor-faktor yang sering digunakan dalam mengevaluasi kepuasan terhadap suatu produk diantaranya : kinerja, keistimewaan tambahan, daya tahan, dan daya tarik terhadap panca indra (Tjiptono, 2006).

Kualitas jasa menjadi salah satu keharusan yang dilakukan perusahaan supaya mampu bertahan dan tetap mendapatkan kepercayaan dari pada nasabahnya. Pola konsumsi dan gaya hidup menuntut perusahaan mampu memberikan produk jasa yang berkualitas (Lupiyoadi, 2001).

\section{Pelatihan dan pengembangan}

Menurut Andrew E. Sikula mengemukakan bahwa pelatihan dan pengenbangan adalah: "pelatihan merupakan suatu proses pendidikan jangka pendek yang mempergunakan prosedur sistematis dan terorganisir. Pegawai non menejerial mempelajari pengetahuan dan keterampilan teknis dalam tujuan yang terbatas. Pengembangan merupakan suatu proses pendidikan jangka panjang yang mempergunakan prosedur sistematis dan terorganisasi yang pegawai manajerialnya mempelajari pengetahuan konseptual dan teoritis untuk mencapai tujuan yang umum (Mangkonegara, 2003). 


\section{| Jurnal Kajian Ekonomi \& Bisnis Islam}

\section{Vol 3 No 2 (2020) 233-251 P-ISSN 2620-295 E-ISSN 2747-0490 DOI: 1047467/elmal.v3i2.571}

Pelatihan dan pengembangan adalah proses untuk melatih para karyawan baru atau karyawan yang akan memperoleh penempatan baru dengan keterampilan dasar yang diperlukan untuk melaksanakan pekerjaannya dan fokus dari pelatihan tersebut adalah untuk pekerjaan sekarang. Sedangkan yang untuk sifatnya jangka panjang dan bertujuan untuk mengembangkan kemampuan karyawan untuk tugas yang akan dihadapi mendatang disebut pengembangan (Jusmaliani, 2014).

Program pelatihan bertujuan untuk memperbaiki penguasaan berbagai keterampilan dan teknik pelaksanaan kerja tertentu untuk kebutuhan sekarang, sedangkan pengembangan bertujuan untuk menyiapkan pegawainya siap memangku jabatan dimasa yang akan datang (Triyono, 2012).

Etika berasal dari bahasa latin yaitu 'etos' yang berarti kebiasaan. Sedangkan bahasa Arabnya 'akhlak' yang berarti budi pekerti. Keduanya dapat diartikan sebagai suatu kebiasaan atau adat istiadat yang menunjuk kepada perilaku manusia itu sendiri, tindakan atau sikap yang dianggap benar atau baik (Hasan, 2006). Etika kerja islami menekankan pekerjaan kreatif sebagai sumber kebahagiaan dan prestasi. Kerja keras dianggap sebagai kebajikan dan orang yang bekerja keras lebih besar kemungkinan hidupnya akan lebih maaju, sebaliknya tidak bekerja keras dianggap menyebabkan kegagalan. Nilai etika kerja islami dihasilkan dari keinginan diri sendiri, tanpa adanya paksaan dari pihak manapun.

Dalam buku manajemen personalia dan sumber daya manusia, pelatihan adalah untuk memperbaiki penguasaan berbagai keterampilan dan teknik pelaksanaan kerja tertentu, sebab pelatihan program untuk menyiapkan para karyawan untuk melakukan pekerjaan sekarang. Sedangkan pengembangan adalah seorang manajemen ingin menyiapkan para karyawan untuk memegang tanggung jawab pekerjaan di awktu yang akan dating (Handoko, 2001).

Pelatihan dan pengembangan menurut beberapa definisi disimpulkan bahwa pelatihan bertujuan untuk memberikan keterampilan kepada calon karyawab baru sebelum bekerja. Pelatihan juga ditunjukkan untuk membiasakan calon karyawan dalam bekerja. Oleh karena itu dalam pelatihan calon pegawai dilatih bagaimana cara bekerja yang baik serta memahami visi dan misi yang terdapat di sebuah perusahaan. Disamping pelatihan, karyawan dalam perusahaan juga harus melakukan pengembangan terhadap seluruh karyawannya. Pengembangan keryawan diutamakan untuk karyawan lama dalam rangka menyegarkan kembali dan untuk meningkatkan kemampuannya (Kasmir, 2000).

\section{Penelitian Sebelumnya}

Adapun penelitian sebelumnya yang terkait dengan Analisis Peningkatan Kinerja Karyawan Melalui Pelatihan Dan Pengembangan Pada Bank Muamalat Cabang Medan Balai Kota adalah penelitian oleh Agus Handayani tahun 2011 yang berjudul Analisis Peningkatan Kinerja Karyawan Melalui Pelatihan Dan Pengembangan Pada BRI Syariah. 


\section{Vol 3 No 2 (2020) 233-251 P-ISSN 2620-295 E-ISSN 2747-0490 DOI: 1047467/elmal.v3i2.571}

\section{METODE PENELITIAN}

Penelitian bersifat kualitatif dengan memaparkan data secara deskriptif sehingga memberikan pemahaman dan kejelasan dari penelitian. Variabel yang ada dalam penelitian ini adalah analisi peningkatan kinerja karyawan melalui pelatihan dan pengembangan pada Bank Muamalat Cabang Medan.

Adapun lokasi penelitian mengenai analisi peningkatan kinerja karyawan melalui pelatihan dan pengembangan pada Bank Muamalat Cabang Medan Balai Kota adalah di Bank Muamalat Cabang Pembantu Stabat. Waktu penelitian adalah di bulan April s/d Mei 2017.

Penelitian ini menggunakan dua jenis sumber data, sebagai berikut: Data primer adalah data yang diperoleh dari instansi atau lembaga terkait yang dianggap relevan dengan tujuan penelitian melalui dokumentasi, observasi, wawancara dan kuisioner. Data sekunder adalah data yang diperoleh melalui penulusuran berbagai referensi yang terkait dengan analisi peningkatan kinerja karyawan melalui pelatihan dan pengembangan pada Bank Muamalat Cabang Medan Balai Kota. Adapun data sekunder tersebut terdiri atas: buku-buku, undang-undang, artikel, majalah, ensiklopidia, kamus, dan bahan acuan lainnya.

Adapun metode pengumpulan data yang digunakan dalam penelitian ini adalah sebagai berikut: Observasi adalah metode pengumpulan data yang digunakan untuk menghimpun data penelitian melalui pengamatan dan penginderaan (Bungin, 2009). Observasi dalam penelitian ini adalah melakukan pengamatan langsung di lapangan untuk mengetahui kondisi subjektif di seputar lokasi penelitian yaitu analisi peningkatan kinerja karyawan melalui pelatihan dan pengembangan pada Bank Muamalat Cabang Medan Balai Kota. Dokumentasi berasal dari kata dokumen yang artinya barang-barang yang tertulis. Dalam melaksanakan metode dokumentasi, peneliti menyelidiki bendabenda tertulis seperti buku-buku, majalah, dokumen, catatan harian, dan sebagainya. Wawancara merupakan tekhnik pengumpulan data untuk mendapatkan keterangan lisan melalui tanya jawab dan berhadapan langsung dengan orang yang memberikan keterangan terkait objek masalah yang di angkat oleh peneliti (Usman dan Purnomo Setiady Akbar, 2001).

Teknik pengumpulan data yang akan digunakan adalah Wawancara, yaitu suatu cara pengumpulan data dengan mengajukan pertanyaan-pertanyaan yang sistematis dengan atau tanpa bantuan suatu daftar pertanyaan. Dalam hal ini pengumpulan data yang dilakukan dengan wawancara tidak hanya terbatas pada pokok masalah saja, tetapi juga ke hal-hal lain yang dianggap perlu dan berhubungan dengan masalah yang diteliti. Wawancara dilakukan untuk memperoleh informasi secara langsung dengan para pegawai bank dan pihak-pihak yang terkait. Pedoman wawancara yang dilakukan ada dua yaitu pedoman wawancara tidak terstruktur dan pedoman terstruktur. Pedoman wawancaara tidak terstruktur yaitu pedoman wawancara yang hanya memuat garis besar yang ditanyakan. 


\section{Jurnal Kajian Ekonomi \& Bisnis Islam}

\section{Vol 3 No 2 (2020) 233-251 P-ISSN 2620-295 E-ISSN 2747-0490 DOI: 1047467/elmal.v3i2.571}

\section{HASIL DAN PEMBAHASAN}

Berdasarkan hasil wawancara yang peneliti lakukan terhadap kepala cabang, karyawan, dan nasabah. Hasil wawancara dengan kepala cabang Bank Muamalat Cabang pembantu Stabat, keadaan lingkungan bank Muamalat Cabang Pembantu Stabat sangat strategis, karena berada di jalan lintasn kota Stabat. Terdapat sara dan prasarana yang sangat lengkap, dan membantu nasabah untuk bertransakasi. Bank Muamalat adalah Bank Syariah pertama di Indonesia. Struktur organisasi Bank Muamalat sangat baik sama seperti Bank Syariah pada umumnya. Sarana dan prasara yang dimiliki sangat lah lengkap, mulai dari gedung, karyawan dan fasilitas yang lainnya. Etika karyawan sangat baik, karena mereka telah dididik dan dibekali ilmu yang baik mengenai etika berbicara dan bertransaksi dengan nasabah. Karyawan selalu diajarkan menggunakan bahasa yang sopan dan lemah lembut.

Karyawan Bank Muamalat diberikan pelatihan yang sangat baik. Sebelum memasuki dunia perbankan, mereka diajari cara berbicara, menyapa, mengatasi kendala ketika ganggguan jaringan tidak stabil dan mereka diajari untuk saling menolong.

Hasil wawancara dengan Karyawan Bank Muamalat cabang Pembantu Stabat. Karyawan Bank adalah pekerjaan yang cukup menantang dan membutuhkan kesabaran. Menghadapi nasabah, memberika senyum, berbicara dengan sopan dan santun serta ramah tamah. Sering kali menghadapi nasabah yang kurang paham mengenai mengenai tata cara menabung, itu tugas dari teller untuk menjelaska. Memberikan penjelasan yang mudah dimengerti oleh nasabah dan selalu mengedepankan profesionalitas dalam bekerja.

Karyawan Bank harus memiliki wawasan luas dalam melaksanakan tanggung jawabnya. Tidak mudah panik dalam menghadapi antrian nasabah yang sangat panjang. Tetap memberikan senyuman hangat walaupun dalam keadaan lelah. Memiliki suara yang lemah lembut dan santun dalam berbicara.

Pelatihan dan pengembangan yang diberikan kepada karyawan bertujuan untuk memajukan dunia perbankan. Karyawan merasa senang mendapatkan pelatiah dari bank muamalat, hal ini bisa memajukan karir mereka di dunia perbankan dan semakin tangguh dalam menghadapi masalah yang terjadi di dunia nyata kerja.

Kesimpulannya, sebagai Karyawan Bank harus bertanggung jawab. Sopan dan ramah. Menjunjung profesionalisme dan tepat waktu serta mandiri. Serta mampu mengembangkan kemampuannya.

\section{KESIMPULAN DAN SARAN}

Berdasarkan hasil penelitian dan pembahasan yang telah disampaikan pada bab sebelumnya, berikut akan dikemukakan beberapa kesimpulan yang dapat diambil mengenai Analisis Peningkatan Kinerja Karyawan Melalui Pelatihan Dan Pengembangan Pada Bank Muamalat Cabang Medan Balai Kota. 


\section{| Jurnal Kajian Ekonomi \& Bisnis Islam}

\section{Vol 3 No 2 (2020) 233-251 P-ISSN 2620-295 E-ISSN 2747-0490 DOI: 1047467/elmal.v3i2.571}

Kepala Cabang berperan sangat penting dalam memajukan dunia Perbankan. Kepala Cabang haruslah orang yang bertanggung jawab, ramah, sopan, jujur, teliti dan tepat waktu. Selain itu, karyawan adalah orang yang dititipkan amanah oleh Bank untuk menyimpan dana sementara yang diberikan oleh nasabah. Karyawan haruslah sabar dalam melayani nasabah, tetap tersenyum walaupun dalam keadaan yang sangat melelahkan. Pelayanan yang diberika oleh seorang teller haruslah baik, agar nasabah merasa nyaman dan loyal kepada Bank tersebut. Dari pemaparan diatas dapat disimpulkan, bahwa Kepala Cabang dan Karyawan Bank Muamalat Cabang Medana Balai Kota sangat baik, ramah, sopan serta teliti.

Cara kerja karyawan dalam meningkatkan kualitas pelayanan sangat baik. Respons nasabah juga sangat baik. Nasabah menjadi loyal terhadap Bank Muamalat. Sistem bahi hasil yang ditawarkan sangat menarik minat masyarakat untuk bergabung menjadi nasabah.

Nasabah merasa puas akan pelayanan yang diberikan karyawan. Semua karyawan Bank Muamalat sangat baik, ramah serta sopan. Pelatihan dan pengembangan yang diberikan bank sangat baik untuk memajukan kinerja karyawan. Karyawan merasa bangga mendapatkan pelatihan dari bank. Karyawan menjadi semakin percaya diri dalam menjalankan tugas yang sudah diamanahkan.

Beberapa saran yang ingin penulis sampaikan dalam penelitian ini adalah sebagai berikut: Bank Muamalat hendaknya lebih meningkatkan lagi hubungan kerja dan komunikasi yang baik antar sesama karyawan, dan antara sesama nasabah, agar terjalin hubungan komunikasi yang lebih baik lagi.

Bagi karyawan saya harap dapat meningkatkan kualitas layanan dan kinerja dalam bekerja agar nasabah yang menabung menjadi lebih nyaman dan bisa manrik para calon nasabah untuk bergabung menjadi nasabah Bank Muamalat.

Bagi para peneliti yang akan datang saya berharap agar dapat memilih juduljudul yang memiliki kevaliditasan terhadap objek yang diteliti agar penelitian yang dilakukan dapat teruji kebenarannya dan memiliki manfaat bagi pembaca dan dunia akademisi.

\section{DAFTAR PUSTAKA}

Abdullah, Ma'ruf. 2014. Manajemen dan Evaluasi Kinerja Karyawan, Yogyakarta: Aswajaya Persido.

Antoni, Muhammad Syafi'i. 2000. Bank Syariah dari Teori ke Praktik, jakarta: Gema Insanai.

Ardila, Tika. 2006. Fungsi Kinerja, Bandung: Rineka Cipta.

Bungin, Burhan. 2009. Penelitian Kualitatif, Jakarta: Kencana.

Departemen Agama RI. 2010. Al-Qur'an dan Terjemah, Jakarta: Pustaka assalam.

Djohar Arifin dan Abdul Aziz. 2013. Etika Bisnis Islami, Yogyakarta: Deepublish. 


\section{| Jurnal Kajian Ekonomi \& Bisnis Islam}

\section{Vol 3 No 2 (2020) 233-251 P-ISSN 2620-295 E-ISSN 2747-0490 DOI: 1047467/elmal.v3i2.571}

F. Winami dan G. Sugiyarso. 2006. Administrasi Gaji dan Upah, Yogyakarta: Pustaka Widyatama

Fathani, Abduraramat. 2006. Organisasi dan Manajemen Sumber Daya Manusia, Jakarta : Rineka Cipta.

Fendy Levy Kambey, Dkk, 2000. Pengaruh Pembinaan Pelatihan dan Pengembangan Pemberdayaan dan Pertisipasi terhadap Kinerja Karyawan, Jakarta: Rineka Cipta.

Frans Margin Suseno. 1997. 13 Tokoh Etika, Yogyakarta: Kanisius.

Handoko, T. Hani. 2001 Manajemen Personalia dan Sumber Daya Manusia, Yogyakarta: BPFE-Yogyakarta.

Hani Handoko. 2001. Manajemen Personalia dan Sumber daya Manusia, Yogyakarta: BPFE.

Hasan, Ali. 2009, Manajemen Bisnis Syari'ah, Yogyakarta : Pustaka Belajar.

Husain Usman dan Purnomo Setiady Akbar.2001. Metodologi Penelitian Sosial, Cet. IV; Jakarta: PT. Bumi Aksara,

Ibrahim Abu Sinn, Ahmad. 2006. Manajemen Syariah Sebuah Kajian Historis dan Kontemporer, Jakarta: PT. Raja Grafindo Persada.

Ismail. 2011. Perbankan Syariah, Jakarta: Kencana Prenada Media Group. Jusmaliani. 2014. Pengelolaan Sumber Daya Insani, Jakarta: Bumi Aksara.

Kashmir. 2000. Manajeman Perbankan, Jakarta: PT. Raja Grafindo Persada.

Kasmir. 2000. Manajemen Perbankan, Jakarta: PT. Raja Grafindo.

Kasmir. 2006. Bank dan Lembaga Keuangan Lainnya, Jakarta: Raja Grafindo.

Kasmir. 2010. Manajemen Perbankan, Jakarta: Raja Grafindo Persada.

Kotler, Philip Manajemen Pemasaran: Analisis, Perencanaan, Implementasi dan Kontrol, Edisi 9, Terjemahan : Hendra Tegush, Jakarta: Prendhallindo, 2000.

Lubis, Suhrawardi K. 2000. Hukum Ekonomi Islam, Jakarta: Sinar Grafika, 2000.

Lupiyoadi, Rambat. 2001. Manajemen Pemasaran, Jakarta: Salemba Empat.

Mamik Eko dkk. 2000. Pengaruh Pelatihan, Kompensasi terhadap Kepuasan Kerja Karyawan dan Kinerja Karyawan, Vol, 7 No. 1, Malang: Universitas Brawijaya Malang

Mangkunegara, A. A. Anwar Prabu. 2003. Perencanaan dan Pengembangan Sumber Daya Manusia. Bandung: PT. Refika Aditama.

Mannan, M.A. 1994. Teori dan Praktek Ekonomi Islam, Yogyakarta: Dana Bhakti.

Muhammad. 2006. Dasar-dasar Manajemen Bank Syariah Edisi Revisi. Yogyakarta: UII Pres.

Ridwan, Ahmad Hasan. 2004. BMT \& Bank Islam : Instrumen Lembaga Keuangan Syariah, Bandung:Pustaka Bumi Quraisy.

Rivai, Veithzal. 2004. Manajemen Sumber Daya Manusia untuk Perusahaan dari Teori ke Praktik, Jakarta: Raja Grafindo Persada.

Sudarmanto. 2009. Kinerja dan Pengembangan Kompetensi SDM, Yogyakarta: Pustaka Pelajar. 


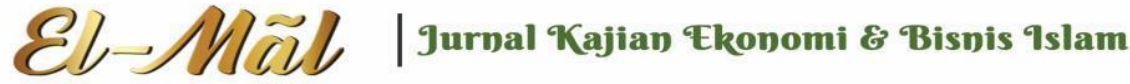

\section{Vol 3 No 2 (2020) 233-251 P-ISSN 2620-295 E-ISSN 2747-0490 DOI: 1047467/elmal.v3i2.571}

Suranto Aw. 2011. "Komunikasi Interpersonal", Yogyakarta:Graha Ilmu.

Suryani, Tatik. 2008. Perilaku Konsumen: Implementasi Strategi Pemasaran, Yogyakarta: Graha Ilmu.

Sutan Remi Sjahdeni. 2005. Perbankan Islam dan Kedudukannya dalam Tata Hukum Indonesia, Jakarta: Grafiti.

Sutrisno, Edy. 2010. Manajemen Sumber Daya Manusia, Jakarta: Kencana.

Syafei, Buyung Upah Minimum dan Kesejahteraan Buruh, vol5 jurnal di akses pada tanggal 24 Januari 2016.

Tim Penyusun Phoenix. 2009. Kamus Besar Bahasa Indonesia, Jakarta: PT. Media Pustaka Phoenix.

Triyono, Ayon. 2012. Paradigma Baru Manajemen Sumber Daya Manusia, Jakarta Selatan: Suka Buku.

Undang Ahmd Kamaludin dan Muhammad Alfan. 2010. Etika Manajemen Islam, Bandung: CV. Pustaka Setia.

Undang-Undang Republik Indonesia Nomor 10 Tahun 1998 Tentang Perubahan Atas Undang-Undang Nomor 7 Tahun 1992 Tentang Perbankan. 